(c) American Dairy Science Association, 2006.

\title{
Extraction and Partial Characterization of Proteolytic Activities from the Cell Surface of Lactobacillus helveticus Zuc2
}

\author{
G. Scolari, ${ }^{1}$ M. Vescovo, C. Zacconi, and F. Vescovi \\ Istituto Microbiologia, Università Cattolica del Sacro Cuore (UCSC), via Emilia parmense, 84, 29100 Piacenza, Italy
}

\begin{abstract}
Proteolytic activities were extracted from a dairy Lactobacillus helveticus strain and partially characterized. A first cell envelope proteinase (CEP) was extracted using a high ionic strength buffer, both in the presence and in the absence of $\mathrm{Ca}^{2+}$. Moreover, cell treatment by $5 M \mathrm{LiCl}$ allowed for the selective removal of the S-layer protein and CEP, suggesting an enzyme ionic linkage to the cell envelope similar to that observed for the Slayer structure. The enzyme specificity against $\alpha_{\mathrm{s} 1}-\mathrm{CN}$ (f1-23) showed unusual activity on the $\mathrm{Lys}_{3}-\mathrm{His}_{4}$ bond compared with other proteinases of the same species. A second proteinase appeared to be linked to the cell membrane because it was extractable only after membrane disgregation by detergents. Its specificity against $\mathrm{CN}$ fractions and $\alpha_{\mathrm{s} 1}-\mathrm{CN}$ (f1-23) was different from that of the first CEP; moreover, the measured activity was lower than that of CEP.
\end{abstract}

Key words: Lactobacillus helveticus, cell envelope, proteinase, specificity

\section{INTRODUCTION}

Lactobacillus helveticus represents the prevailing species among the thermophilic bacteria of natural whey starter cultures, and it plays an essential role in the ripening of different cheeses, such as Italian hard cheese and Swiss-type cheese. Morishita et al. (1981) demonstrated that $L$. helveticus strains are auxotrophic for most of the AA. Therefore, because of the low free AA content, its growth in milk depends on an extensive $\mathrm{CN}$ breakdown by proteolytic enzymes whose activity is considered the strongest among the lactic acid bacteria (Kunji et al., 1996). For this peculiar characteristic, its use has been suggested as a starter adjunct to Cheddar cheese milk because an attenuated culture enhances the flavor development (Makdor et al., 2000). Casein breakdown results from the action of extracellular proteinase(s), and the hydrolysis products (from 4 to $18 \mathrm{AA}$ )

Received September 30, 2005.

Accepted April 17, 2006.

${ }^{1}$ Corresponding author: gianluigi.scolari@unicatt.it are translocated into the bacterial cell via an oligopetide transport system. Various cytoplasmatic peptidases, with partially overlapping specificities, then degrade the internalized oligopeptides into free AA (Kunji et al., 1996).

Several reports are available on the cell envelope proteinase (CEP) of L. helveticus, which display a strong heterogeneity among such enzymes (MartinHernandez et al., 1994; Ono et al., 1997; Hébert et al., 1999).

In some cases, an appreciable release of CEP from L. helveticus strains can be achieved by use of a calciumfree buffer, such as that obtained for lactococcal proteinase (Ono et al., 1997). On the contrary, CEP of the $L$. helveticus L89 and CRL 1062 strains showed a strong membrane-bound character and was poorly released in a calcium-free extraction buffer (Martin-Hernandez et al., 1994; Hébert et al., 1999). Lactobacillus helveticus CEP show a wide heterogeneity in the relative molecular mass $\left(\boldsymbol{M}_{\mathbf{r}}\right)$ of purified enzymes (ranging from 45 to $180 \mathrm{kDa}$ ), immunological properties (Yamamoto et al., 1998), and CN breakdown specificity (Ono et al., 1997). Moreover, the proteolytic system of this species is considered to be useful for the production of bioactive peptides; in fact, several bioactive peptides are released from $\mathrm{CN}$ either during milk fermentation by strains of this genus (Matar et al., 2001; Scolari et al., 2002; Seppo et al., 2003) or by their isolated proteinases (Maeno et al., 1996).

Pederson et al. (1999) demonstrated the presence of 2 different CEP in a PrtH deletion derivative of the CNRZ 32 strain, obtained by gene replacement. Moreover, a gene ( $h t r \mathrm{~A})$ coding for a stress-inducible Htr-like protein from L. helveticus CNRZ 32 has been cloned, sequenced, and characterized (Smeds et al., 1998). This protein carries the characteristic catalytic domain of trypsin-like proteases, and the authors proposed the location of HtrA of $L$. helveticus to be on the outer surface of the plasma membrane, on the basis of the AA sequence.

This paper describes the extraction of 2 proteinases from a strongly proteolytic $L$. helveticus strain and the partial characterization of the most loosely CEPbound enzyme. 
Table 1. Buffers used in the cell envelope proteinase extraction trials ${ }^{1}$

\begin{tabular}{|c|c|c|c|}
\hline Extractant & $\mathrm{pH}$ & $\begin{array}{l}\text { Concentration } \\
(M)\end{array}$ & Addition \\
\hline $\mathrm{P}_{\mathrm{i}}$ & 7.0 & $0.05,0.1,0.25,0.75,0.50,1.00$ & - \\
\hline $\mathrm{P}_{\mathrm{i}}$ & 7.0 & 0.5 & PMSF (1 mM) \\
\hline $\mathrm{P}_{\mathrm{i}}$ & 7.0 & 0.5 & EDTA $(20 \mathrm{~m} M)$ \\
\hline MES & 7.0 & 0.5 & - \\
\hline MES & 7.0 & 0.5 & $\mathrm{CaCl}_{2}(20 \mathrm{~m} M)$ \\
\hline $\mathrm{LiCl}$ & - & 5 & - \\
\hline
\end{tabular}

${ }^{1} \mathrm{P}_{\mathrm{i}}=$ phosphate buffer; PMSF = phenyl-methyl sulfonyl fluoride; MES = morpholine-ethane sulfonic acid.

\section{MATERIALS AND METHODS}

\section{Chemicals and Chromatographic Materials}

Inhibitors, lysozyme, Igepal Ca-360, and alkaline peptidase, as well as the $\alpha$-CN, $\beta$-CN, and $\kappa$-CN fractions, were obtained from Sigma (Sigma Chemical Co. St. Louis, MO). The SDS molecular weight standard was from Bio-Rad Laboratories (Hercules, CA). Succinyl-Ala-Ala-Phe-7-amido-4-methylcoumarin (AMC), benzoyl-Pro-Phe-Arg-AMC, benzoyl-Phe-Val-Arg-AMC, and benzoyl-Val-Gly-Arg-AMC were obtained from Bachem (Bubendorf, Switzerland).

\section{Strains and Culture Conditions}

The L. helveticus Zuc2 used in this study was previously isolated from natural whey culture for Grana Padano cheese and identified by biochemical tests, randomly amplified polymorphic DNA (RAPD)-PCR analysis, and the electrophoretic mobility of X-prolyl-dipeptidyl aminopeptidase (Scolari and Vescovo, 2004). It was maintained in filter-sterilized cheese whey under liquid nitrogen vapor at the collection of the UCSC Microbiology Institute (Piacenza, Italy) and, when required, was subcultured overnight in the same medium at $44^{\circ} \mathrm{C}$.

\section{Proteinase Extraction and Purification}

Lactobacillus helveticus Zuc2 cells from an overnight culture $(250 \mathrm{~mL})$ were harvested by centrifugation at $3,000 \times g, 4^{\circ} \mathrm{C}$, for $10 \mathrm{~min}$, washed twice in $50 \mathrm{mM} \beta$ glycerolphosphate buffer, $\mathrm{pH} 7.0$, and $15 \mathrm{mM} \mathrm{CaCl}_{2}$ and resuspended to 1:40 of their original volume in each of the extraction buffers listed in Table 1. Bacterial cells were incubated at $37^{\circ} \mathrm{C}$ for 30 min under mild agitation to extract CEP, and were successively removed from suspension by centrifugation at $12,000 \times g, 4^{\circ} \mathrm{C}$, for $10 \mathrm{~min}$. Supernatants were assayed for cell lysis by measuring the intracellular lactate dehydrogenase (EC 1.1.1.127) and X-prolyl-dipeptidyl aminopeptidase (EC 3.4.14.5) activities according to Scolari and Vescovo (1996) before storage at $-80^{\circ} \mathrm{C}$.
The proteinase extracted by $0.5 M$ phosphate $\left(\mathrm{P}_{\mathrm{i}}\right)$ buffer, $\mathrm{pH} 7.0$, was loaded $(750 \mu \mathrm{L})$ onto a gel filtration Superdex 200 HR 10/30 column (Pharmacia Biotech, Uppsala, Sweden) previously calibrated by a gel filtration high molecular weight calibration kit (Pharmacia Biotech), and samples were eluted using $50 \mathrm{~m} M \mathrm{P}_{\mathrm{i}}$ buffer, $\mathrm{pH} 7.0$, and $150 \mathrm{mM} \mathrm{NaCl}$ at a flow rate of 0.4 $\mathrm{mL} / \mathrm{min}$. Eluted fractions $(5 \mathrm{~mL})$ were monitored by a UV detector $(280 \mathrm{~nm})$ and assayed for proteolytic activity; the active fractions were concentrated sixfold by diafiltration on 10-kDa molecular weight cut-off centricon concentrators (Millipore, Bedford, MA) against the equilibration buffer of the next chromatography. The second purification step was performed on a MonoQ ion-exchange column (Pharmacia Biotech) equilibrated with $20 \mathrm{mM} \mathrm{P}_{\mathrm{i}}$ buffer, $\mathrm{pH} 7.5$, at a flow rate of $1 \mathrm{~mL} /$ min. The enzyme was eluted by a 30-min linear gradient of 0 to $0.5 \mathrm{M} \mathrm{NaCl}$ in the equilibration buffer, and the active fractions (containing $3.5 \mu \mathrm{g} / \mathrm{mL}$ of the purified enzyme) were stored at $-80^{\circ} \mathrm{C}$ until use (CEP fractions). Moreover, after cell fractionation, the proteolytic activity extracted from the membrane fractions was subjected to the same chromatographic steps as CEP purification, but using a linear gradient of 0 to $3 \mathrm{M} \mathrm{NaCl}$ for MonoQ chromatography. All the above steps were performed at $4^{\circ} \mathrm{C}$.

\section{Bacterial Cell Fractionation}

Washed cells from an overnight culture were obtained as described in the previous section. To obtain protoplasts and the cell wall fraction, pellets were suspended to 1:25 of their original volume in the digestion buffer and processed as described by Scolari and Vescovo (1996). Protoplasts were separated from the supernatant (cell wall fraction) by centrifugation at $1,300 \times$ $\mathrm{g}, 4^{\circ} \mathrm{C}$, for $10 \mathrm{~min}$. To remove the high concentration of protoplasts stabilizing sucrose $(17 \%)$, the cell wall fraction was subjected to dialysis for $24 \mathrm{~h}$ at $4^{\circ} \mathrm{C}$. Pellets containing protoplasts were washed with the digestion buffer and resuspended at 1:25 of the original culture volume in digestion buffer deprived of lysozyme and saccharose. After mechanical disruption of the protoplasts by mild sonication in ice-cold $50 \mathrm{~m} M \mathrm{P}_{\mathrm{i}}$ buffer, $\mathrm{pH}$ 7.0, unbroken particles were selectively settled by centrifugation at $1,000 \times g, 4^{\circ} \mathrm{C}$, for $10 \mathrm{~min}$; centrifugation of the supernatant at $16,000 \times g, 4^{\circ} \mathrm{C}$, for $10 \mathrm{~min}$ produced membrane (pellet) and cytoplasmic (supernatant) fractions.

The washed membranes were suspended to the volume of the cytoplasmic fraction using the same buffer with $1 \%$ (vol/vol) Igepal Ca-360 added, and were almost completely dissolved by stirring for $2 \mathrm{~h}$ at $4^{\circ} \mathrm{C}$. The detergent was removed from the solubilized mem- 
branes by exhaustive diafiltration on $10-\mathrm{kDa}$ molecular weight cut-off centriprep concentrators (Amicon Inc., Beverly MA) using $20 \mathrm{mM} \mathrm{P}_{\mathrm{i}}$ buffer, $\mathrm{pH}$ 7.5. Cell fractions were assayed for proteolytic activity.

\section{Proteinase Characterization}

Cell envelope proteinase fractions were dialyzed against each assay buffer before determination of the enzyme temperature optimum (measured at $\mathrm{pH}$ 7.0) and $\mathrm{pH}$ optimum (measured at $37^{\circ} \mathrm{C}$ ). Proteolytic activity was measured at $30,37,42$, and $55^{\circ} \mathrm{C}$ as indicated in the following sections; measures at the desired $\mathrm{pH}$ values (5.0 to 7.0) were performed using the same substrate in $50 \mathrm{~m} M$ citrate- $\mathrm{P}_{\mathrm{i}}$ buffer.

The effect of inhibitors was evaluated by measuring the activity of the same fractions against caseinate at the conditions described above in the presence or absence of each protease inhibitor: $1 \mathrm{~m} M$ phenyl-methyl sulfonyl fluoride (PMSF), $100 \mu M$ 3,4-dichloroisocoumarin, $1 \mathrm{~m} M$ pepstatin, and $10 \mu M$ E-64 as a thiol-protease inhibitor.

\section{Proteinase Specificity}

Equal volumes of individual CN suspensions $(20 \mathrm{mg} /$ $\mathrm{mL}$ in $50 \mathrm{mM} \mathrm{P}_{\mathrm{i}}$ buffer, $\mathrm{pH}$ 7.0) and CEP fractions (2 $\mathrm{mL}$ ), previously diafiltered in the same buffer at onethird of their original volume, were used to determine $\alpha$-CN, $\beta$-CN, and $\kappa$-CN breakdown by the purified enzyme. Samples for SDS-PAGE analysis were taken after $0,10,60$, and $120 \mathrm{~min}$ of mixture incubation at $37^{\circ} \mathrm{C}$.

To obtain the $\alpha_{\mathrm{s} 1}-\mathrm{CN}$ (f1-23) peptide, $\alpha_{\mathrm{s} 1}$-CN B was purified and the pepsin was hydrolyzed as described by Kaminogawa et al. (1986). The $\alpha_{\mathrm{s} 1}-\mathrm{CN}$ (f1-23) fragment was purified from the hydrolysis mixture by means of semipreparative reversed-phase (RP)-HPLC on a $\mathrm{C}_{18}$ Radial-Pack cartridge (Waters Associates, Milford, MA) in a trifluoroacetic acid- $\mathrm{CH}_{3} \mathrm{CN}$ solvent system (solvent A: $0.115 \%$ trifluoroacetic acid in water; solvent B: $0.1 \%$ trifluoroacetic acid-60\% $\mathrm{CH}_{3} \mathrm{CN}$ in water). Samples were eluted using a 60-min linear gradient from 0 to $100 \%$ solvent $B$ and recorded at $214 \mathrm{~nm}$.

The $\kappa$-CN (f106-169) glycomacropeptide fragment (GMP) was separated from the cheese whey by semipreparative RP-HPLC under the same conditions as used for $\alpha_{\mathrm{s} 1} \mathrm{CN}$ (f1-23) purification and monitored for the presence of sialic acid by the thiobarbituric acid reaction (Sick et al. 1990). Solvent was removed from the GMP-containing fractions by evaporation, and AA analysis was performed according to Scolari et al. (1996) following acid hydrolysis for $24 \mathrm{~h}$ at $110^{\circ} \mathrm{C}$ under vacuum in $6 \mathrm{M} \mathrm{HCl}$ containing $0.1 \%$ (wt/vol) phenol. The peptide was identified by comparing the AA composition with that calculated from the GMP sequence.

Purified $\alpha_{\mathrm{s} 1}$-CN (f1-23) and GMP peptides were incubated (final concentration of each: $3 \mu \mathrm{g} / \mathrm{mL}$ ) with CEP and the membrane proteinase preparations at $37^{\circ} \mathrm{C}$, tracking samples after 10 and 30 min.

The specificity of CEP against the $\alpha_{\mathrm{s} 1}-\mathrm{CN}$ (f1-23) and GMP fragments was analyzed by RP-HPLC separation of the degradation products according to Exterkate et al. (1991) on an ACCQ·Tag RP-C18 column, 3.9 × 150 $\mathrm{mm}$ (Waters Associates). Peaks were collected, dried, and identified by mass spectrometry performed on a laser desorption time-of-flight system (model G2025A; Hewlett-Packard, Palo Alto, CA). Peptides from GMP hydrolysates were identified by $\mathrm{N}$-terminal sequencing and determination of the AA profile.

\section{Proteolytic Activity Measurements and SDS-PAGE Electrophoresis}

Preparations containing proteolytic activity $(3.5 \mu \mathrm{g} /$ $\mathrm{mL}$ for pure CEP and $0.8 \mu \mathrm{g} / \mathrm{mL}$ for protease from membranes) were mixed with the same volume of $1.5 \%$ (wt/

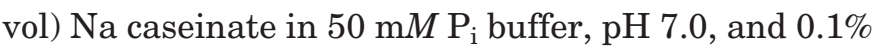
(wt/vol) $\mathrm{NaN}_{3}$, dialyzed against the same buffer, and were incubated overnight at $37^{\circ} \mathrm{C}$; the activity was measured as the increase in optical density at $340 \mathrm{~nm}$ $\left(\mathrm{OD}_{340}\right)$ after o-phthaldialdehyde derivatization according to Scolari et al. (1996).

To detect the presence of endopeptidase activity in the purified fraction of CEP, the dialyzed preparations were separated on native PAGE as described by Scolari and Vescovo (2004); gels were stained after incubation by $0.1 \mathrm{~m} M$ succinyl-Ala-Ala-Phe-AMC, benzoyl-ProPhe-Arg-AMC, benzoyl-Phe-Val-Arg-AMC, and benzoyl-Val-Gly-Arg-AMC in the presence of $0.8 \mathrm{U} / \mathrm{mL}$ of alkaline peptidase (EC 3.4.11.10), under the conditions reported by the same authors. Substrates were chosen following the indications of Christensen et al. (2003).

Sodium dodecyl sulfate-PAGE electrophoresis was carried out as described by Scolari et al. (1996) using a Mini-Protean electrophoretic cell (Bio-Rad Laboratories). Hydrolyzed CN and enzymatic activity were separated on 12 and $8 \%$ running gels, respectively, and enzyme $M_{\mathrm{r}}$ was determined by a low-range SDS molecular weight standard after Coomassie Brilliant Blue R250 staining; GMP visualization was possible using 5\% (wt/vol) TCA in $10 \%$ acetic acid as the destaining solution.

\section{LiCl Treatments}

The $\mathrm{LiCl}$ extract was exhaustively diafiltered by 30 $\mathrm{kDa}$ molecular weight cut-off centricon against Milli-Q 
water (Waters Millipore, Milan, Italy) until a white precipitate was formed, which was recovered by centrifugation at $12,000 \times \mathrm{g}$ for $10 \mathrm{~min}$ and dissolved to the original extract volume in $50 \mathrm{mM} \mathrm{P}_{\mathrm{i}}, \mathrm{pH}$ 7.0. Both the supernatant and solubilized precipitate were assayed for proteolytic activity, and the specificity of the latter was determined against $\alpha_{\mathrm{s} 1}-\mathrm{CN}$ (f1-23) as described above.

In addition, the proteolytic activity of either intact or LiCl-extracted cells was evaluated. For this purpose, $L$. helveticus Zuc2 cells, obtained as reported above, were treated twice with $3 \mathrm{M} \mathrm{LiCl}$ by mild agitation at $4^{\circ} \mathrm{C}$ for $20 \mathrm{~min}$. Both types of cells were washed and suspended in $50 \mathrm{~m} M \quad \beta$-glycerolphosphate buffer, $\mathrm{pH}$ 7.0 , added to $7 \mu \mathrm{g} / \mathrm{mL}$ of chloramphenicol as a protein synthesis inhibitor and incubated with $\alpha_{\mathrm{s} 1}-\mathrm{CN}$ (f1-23) at $4^{\circ} \mathrm{C}$ for $30 \mathrm{~min}$. The hydrolysis products were separated as described above, and their identification was based on previous results; unknown peaks [from $\alpha_{\mathrm{s} 1^{-}}$ CN (f1-23)] were identified by AA analysis as reported above.

\section{RESULTS}

\section{CEP Extraction}

Lactobacillus helveticus Zuc2 was characterized by strong proteolytic activity toward CN; however, cell incubation in Ca-free buffers was ineffective in releasing such activity from the cell envelope. The recovery of CEP was enhanced by increasing the ionic strength of the extraction buffer. In particular, when using $\mathrm{P}_{\mathrm{i}}$ extraction buffers ranging from 0.05 to $1.00 M$ (Table 1), a logarithmic relationship was evident between the release of CEP, expressed as $\mathrm{OD}_{340}$, and buffer concentrations up to $0.5 M$. Moreover, when using a buffer of still higher ionic strength, less than $40 \%$ of the enzymatic activity was retained on the treated cells (Figure 1). These results suggest the use of a $0.5 M \mathrm{P}_{\mathrm{i}}$ buffer for the CEP extraction and purification steps.

In all the extraction experiments, cell lysis was negligible because of the absence of intracellular enzyme activities (EC 1.1.1.127 and EC 1.1.1.127) in culture supernatants. To exclude a $\mathrm{Ca}^{2+}$-triggered autoproteolytic event in the CEP release mechanism, L. helveticus Zuc2 cells were incubated with $\mathrm{P}_{\mathrm{i}}$ buffer with $20 \mathrm{mM}$ EDTA added, and the same extraction pattern was obtained irrespective of the presence of the additive (Figure 2, lanes 4 and 6). Comparable results were obtained using MES extraction buffer with addition of $20 \mathrm{mM}$ $\mathrm{CaCl}_{2}$. Also, an autoproteolytic release of CEP because of structural changes induced by the ionic strength of the buffer was excluded by adding $1 \mathrm{~m} M$ PMSF (Laan and Konings, 1989) to the $0.5 M \mathrm{P}_{\mathrm{i}}$ extraction buffer. In fact, the same SDS-PAGE profile was obtained in

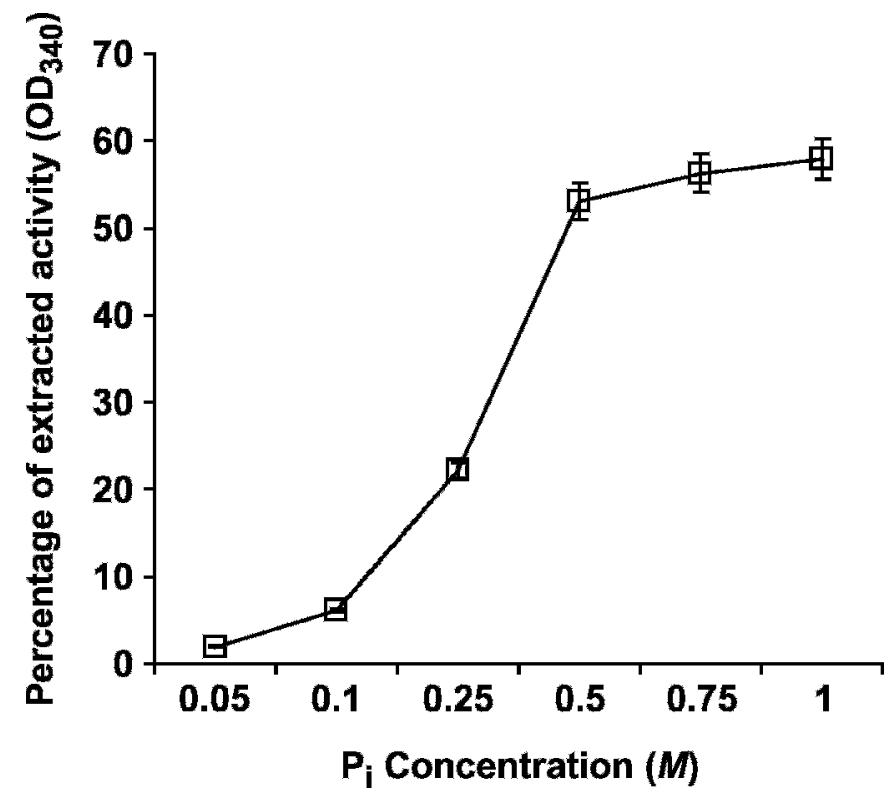

Figure 1. Percentage of the total proteolytic activity extracted from Lactobacillus helveticus Zuc2 cells by phosphate buffer $\left(\mathrm{P}_{\mathrm{i}}\right)$ at increasing ionic strength. The activity is expressed as $\mathrm{OD}_{340}$.

the presence and in the absence of the inhibitor (Figure 2 , lanes 4 and 5). Interestingly, this profile showed a band of approximately $45 \mathrm{kDa}$, with an electrophoretic mobility corresponding to the S-layer monomer, which was also evident in the $5 \mathrm{M} \mathrm{LiCl}$ extract (Mozes and Lortal, 1995; Figure 2, lane 3). It is noteworthy that

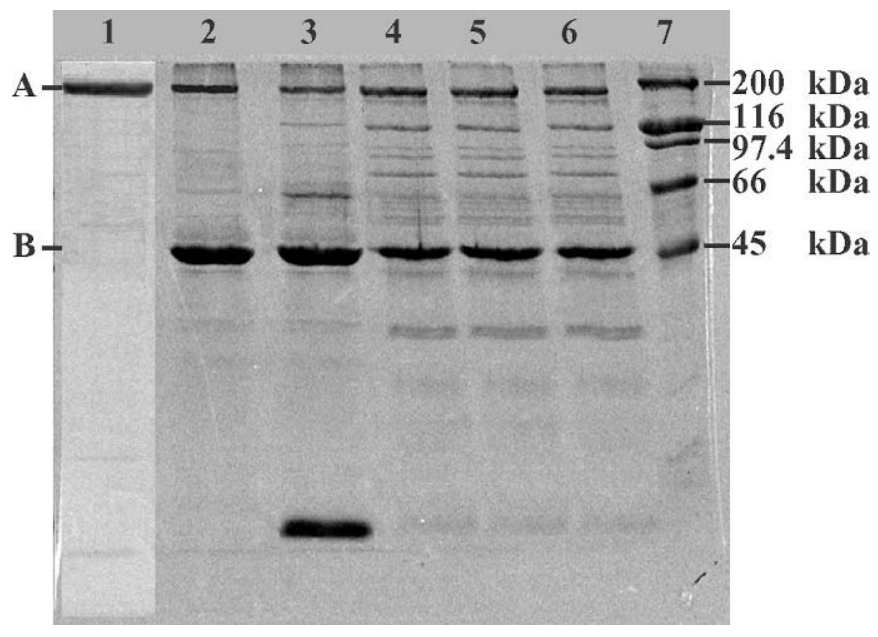

Figure 2. Sodium dodecyl sulfate-PAGE separation of various Lactobacillus helveticus Zuc2 cell envelope proteinase (CEP) extracts. Lane 1: purified CEP. Lanes 2 to 6: various extracts: white precipitate from dialysis (2); $5 M \mathrm{LiCl}$ (3); $0.5 M$ phosphate buffer $\left(\mathrm{P}_{\mathrm{i}}\right)(4) ; 0.5$ $M \mathrm{P}_{\mathrm{i}}+1 \mathrm{~m} M$ PMSF (5); $0.5 M \mathrm{P}_{\mathrm{i}}+20 \mathrm{~m} M$ EDTA (6). Lane 7: SDS molecular mass marker. $\mathrm{A}=180-\mathrm{kDa}$ proteinase; $\mathrm{B}=\mathrm{S}$-layer monomer. 


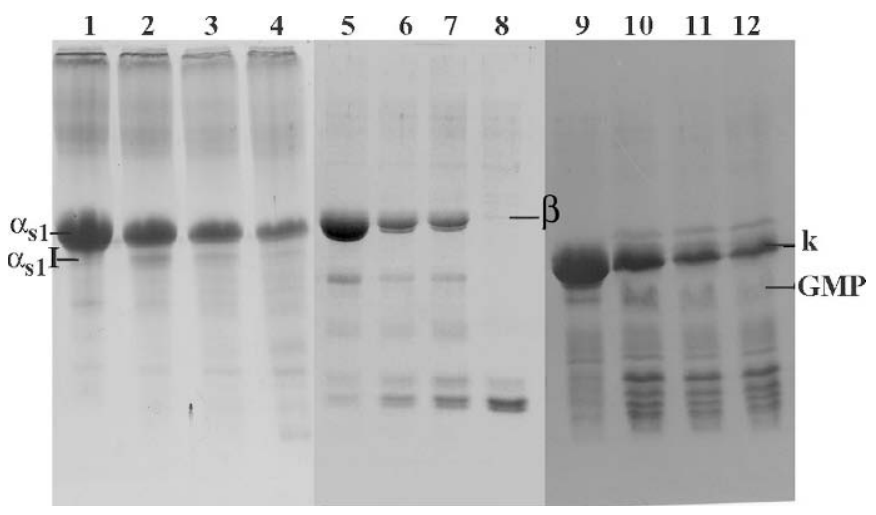

Figure 3. Digestion of $\alpha_{\mathrm{s} 1} \mathrm{CN}$ (lanes 1 to 4 ), $\beta$-CN (lanes 5 to 8), and $\kappa$-CN (lanes 9 to 12) by Lactobacillus helveticus Zuc2 cell envelope proteinase at different incubation times: $0 \mathrm{~min}$, lanes $1,5,9 ; 10 \mathrm{~min}$, lanes 2, 6, 10; $60 \mathrm{~min}$, lanes $3,7,11 ; 120 \mathrm{~min}$, lanes $4,8,12 . \alpha_{\mathrm{s} 1} \mathrm{I}=$ $\alpha_{\mathrm{s} 1}$-CN (f24-199); GMP = glycomacropeptide.

the complete removal of salt from $5 M \mathrm{LiCl}$ extracts by dialysis produced a white precipitate, which retained the original proteolytic activity in its entirety. Sodium dodecyl sulfate-PAGE analysis of the precipitate revealed the presence of 2 main bands corresponding to the S-layer monomer (B) and to the $180-\mathrm{kDa}$ proteinase (A), respectively (Figure 2, lane 2). This could suggest an ability of CEP to associate with the S-layer in $L$. helveticus, as also hypothesized by Pederson et al. (1999) for the L. helveticus CNRZ 32 strain.

Moreover, after complete removal of the S-layer by 3 $M \mathrm{LiCl}$, a small amount (approximately 3 to $5 \%$ ) of the total extractable proteolytic activity was still removable from the cell surface by thorough washing with $0.5 \mathrm{M}$ $\mathrm{P}_{\mathrm{i}}$. The $\alpha_{\mathrm{s} 1}-\mathrm{CN} \mathrm{f}(1-23)$ fragmentation profile of this last extract was the same as that of CEP (data not shown).

\section{Purification and Characterization of CEP}

The purification scheme is shown in Table 2. The high values for specific activity and yield seem to indicate that $0.5 M \mathrm{P}_{\mathrm{i}}$ is a rather selective extractant for $\mathrm{CEP}$, thus allowing for a relatively simple purification process. In fact, the same purification steps permitted only a partial purification of membrane-associated proteinase (MAP) from the membranes, giving a very low yield as well as very low specific activity.

The S-layer associated with CEP, extracted with 0.5 $M \mathrm{P}_{\mathrm{i}}$ buffer, eluted from gel filtration chromatography between thyroglobulin $(669 \mathrm{kDa})$ and ferritin $(440 \mathrm{kDa})$, indicating an approximate native $M_{\mathrm{r}}$ of about $560 \mathrm{kDa}$. Fractions containing proteolytic activity were eluted by subsequent ion-exchange chromatography at an ionic strength of $0.2 \mathrm{M} \mathrm{NaCl}$. On SDS-PAGE they showed a prevailing intense band of $180 \mathrm{kDa} M_{\mathrm{r}}$ (Figure 2, lane
1) that was associated with CEP, thus suggesting a trimeric aggregation of the extracted enzyme, possibly through the $\mathrm{W}$ domain of the molecule. The incubation of native gels of purified CEP fractions with the 4 endopeptidase substrates did not reveal the presence of red bands indicating the presence of such an intracellular enzyme class.

The optimal $\mathrm{pH}$ of $\mathrm{CEP}$ at $37^{\circ} \mathrm{C}$ is approximately 6 , according to values from the literature (Ono et al., 1997). The optimal temperature at $\mathrm{pH} 7.0$ was $44^{\circ} \mathrm{C}$, and the enzyme maintained $40 \%$ of the activity when incubated for $2 \mathrm{~h}$ at $60^{\circ} \mathrm{C}$. Inhibition of the enzyme was complete and irreversible with either $1 \mathrm{~m} M$ PSMF or $100 \mu M$ 3,4-dichloroisocoumarin; $1 \mathrm{~m} M$ pepstatin gave an inhibition of approximately $10 \%$, but the enzyme activity was almost completely restored after inhibitor removal. No inhibition occurred with the thiol-proteinase inhibitor E-64, thus excluding the presence of a cysteine group in the active site.

\section{CEP Specificity}

Hydrolysis of the CN Fractions. The specificity of $\mathrm{CEP}$ on $\alpha_{\mathrm{s} 1}-\mathrm{CN}, \beta$-CN, and $\kappa$ - $\mathrm{CN}$ is reported in Figure 3 . The enzyme showed intense activity toward $\beta-\mathrm{CN}$ even from the first $10 \mathrm{~min}$ of incubation, producing a substantial reduction in the corresponding band. Within this time, a broad band appeared in the hydrolytic profile of $\kappa$-CN that had the characteristic shape and electrophoretic mobility of the purified GMP; it was also possible to observe the formation of a fragment with electrophoretic mobility corresponding to the $\alpha_{\mathrm{s} 1} \mathrm{I}$ peptide in the profile of $\alpha_{\mathrm{s} 1}$-CN hydrolysates, thus indicating the specificity of the enzyme for the $\operatorname{Arg}_{22^{-}}$ $\mathrm{Phe}_{23}$ bond of $\alpha_{\mathrm{s} 1}-\mathrm{CN}$ as well as for the Phe ${ }_{105}-\mathrm{Met}_{106}$ bond of $\kappa$-CN. Both fragments were subsequently partially degraded. At the end of incubation, all the fractions were thoroughly hydrolyzed, and the $\beta$-CN was completely digested.

Specificity Against $\alpha_{s 1}$ CN (f1-23) and GMP. A deeper knowledge of the specificity of CEP was obtained by analyzing the hydrolysis products of both $\alpha_{\mathrm{s} 1}{ }^{-} \mathrm{CN}$ (f123) and GMP. Reversed-phase HPLC digestion profiles of $\alpha_{\mathrm{s} 1}-\mathrm{CN}$ (f1-23) after 10 and $30 \mathrm{~min}$ of incubation, respectively (Figures $4 \mathrm{~A}$ and $4 \mathrm{~B}$ ), showed a complex mixture of hydrolysis products as well as almost complete substrate degradation within the first $10 \mathrm{~min}$ of incubation, confirming the strong activity demonstrated by the enzyme toward the CN fractions. This digestion profile was also obtained by using the white precipitate from the $\mathrm{LiCl}$ extraction, but in a shorter incubation time (data not shown).

The accumulation of $\alpha_{\mathrm{s} 1}$-CN (f1-9), (f10-16), and (f1723) fragments in the first 10 min of incubation could 
Table 2. Summary of the purification of cell envelope proteinase (CEP) and membrane-associated proteinase (MAP) from Lactobacillus helveticus Zuc2

\begin{tabular}{|c|c|c|c|c|c|}
\hline Step & $\begin{array}{l}\text { Total } \\
\text { activity, } \\
\triangle \mathrm{OD}_{340} \\
\end{array}$ & $\begin{array}{l}\text { Total } \\
\text { protein, } \\
\text { mg }\end{array}$ & $\begin{array}{l}\text { Specific } \\
\text { activity, } \\
\Delta \mathrm{OD}_{340} / \mathrm{mg}\end{array}$ & $\begin{array}{l}\text { Purification, } \\
\text { fold }\end{array}$ & $\begin{array}{l}\text { Yield, } \\
\% \\
\end{array}$ \\
\hline \multirow{5}{*}{$\begin{array}{l}\text { Crude extract } \\
\text { Gel filtration chromatography } \\
\text { Ion-exchange chomatography }\end{array}$} & & & - (CEP) & & 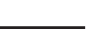 \\
\hline & 3.09 & 166 & $1.86 \times 10^{-2}$ & 1.00 & 100 \\
\hline & 2.47 & 24 & $10.29 \times 10^{-2}$ & 5.53 & 79 \\
\hline & 1.03 & 0.105 & 9.81 & 527.42 & 33 \\
\hline & & & - (MAP) - & & \\
\hline Solubilized membranes & 3.25 & 1,845 & $1.76 \times 10^{-3}$ & 1.00 & 100 \\
\hline Gel filtration chromatography & 2.08 & 647 & $3.21 \times 10^{-3}$ & 1.82 & 35 \\
\hline Ion-exchange chomatography & 0.45 & 37 & $1.22 \times 10^{-2}$ & 6.93 & 2 \\
\hline
\end{tabular}

${ }^{1}$ Activity is expressed as variation in $\mathrm{OD}_{340}$ (optical density at $340 \mathrm{~nm}$ ) after $12 \mathrm{~h}$ of incubation.

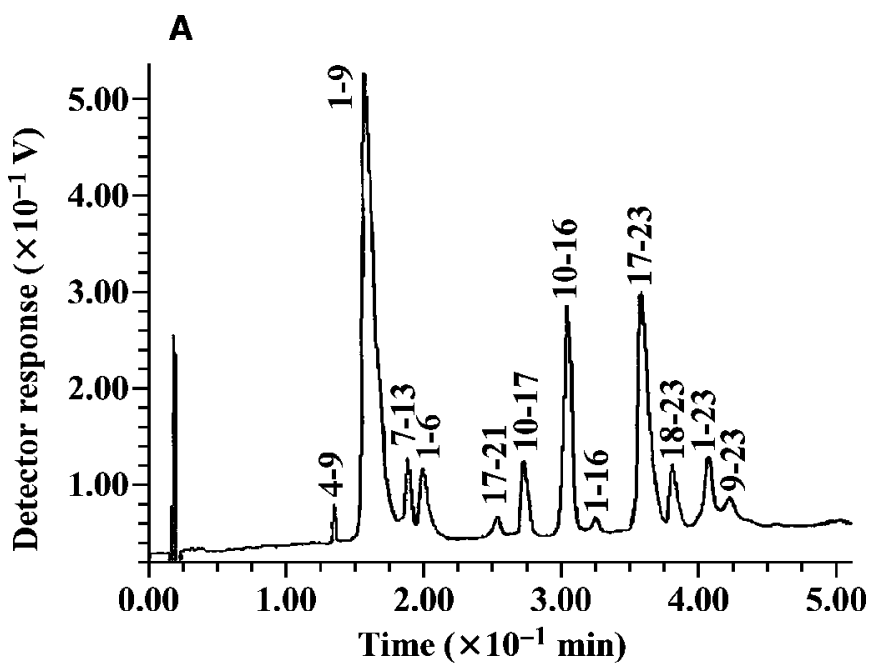

B

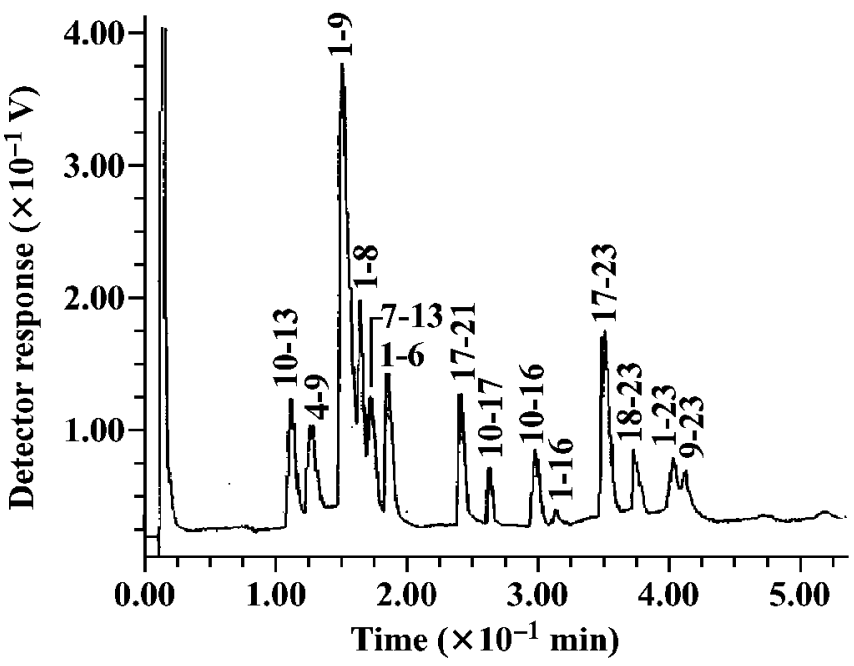

Figure 4. Reversed-phase HPLC patterns of $\alpha_{\mathrm{s} 1}$-CN (f1-23) hydrolysis products after $10 \mathrm{~min}(\mathrm{~A})$ and $30 \mathrm{~min}(\mathrm{~B})$ of incubation at $37^{\circ} \mathrm{C}$ with purified Lactobacillus helveticus Zuc2 cell envelope proteinase. suggest $\mathrm{Gln}_{9}-\mathrm{Gly}_{10}$ and $\mathrm{Leu}_{16}-\mathrm{Asn}_{17}$ bonds as being the primary cleavage sites. Accordingly, the peptide $\alpha_{\mathrm{s} 1}-\mathrm{CN}$ (f1-16) released from splitting of the latter bond could be readily converted to the $\alpha_{\mathrm{s} 1}-\mathrm{CN}$ (f1-9) and (f10-16) fragments, because the amount of $\alpha_{\mathrm{s} 1}-\mathrm{CN}$ (f1-16) in the RP-HPLC profile was consistently low at both incubation times. Similarly, the fragment $\alpha_{\mathrm{s} 1}-\mathrm{CN}$ (f10-23), containing the sensitive $\mathrm{Leu}_{16} \mathrm{Asn}_{17}$ bond, could be degraded to the peptides $\alpha_{\mathrm{s} 1}-\mathrm{CN}$ (f10-16) and (f17-23), because it was not detectable after 10 min of incubation.

Moreover, it is possible to speculate that within the first $10 \mathrm{~min}$, a small amount of the substrate was hydrolyzed at the $\mathrm{Asn}_{17}-\mathrm{Glu}_{18}$ bond, releasing $\alpha_{\mathrm{s} 1}-\mathrm{CN}$ (f1823) and (f10-17), whereas the appearance of the $\alpha_{\mathrm{s} 1^{-}}$ CN (f1-6) and (f7-13) peptides could suggest a similar sensitivity of the $\mathrm{Ile}_{6}-\mathrm{Lys}_{7}$ and $\mathrm{Gln}_{13}-\mathrm{Glu}_{14}$ bonds to CEP activity. One of the possible degradation products of these peptide bond cleavages, the tetra peptide $\mathrm{Glu}_{14}{ }^{-}$ $\mathrm{Val}_{15}-\mathrm{Leu}_{16}-\mathrm{Asn}_{17}$, was not detectable, probably because it did not bind to the column (Oberg et al., 2002).

Among the probable secondary hydrolytic reactions (after $30 \mathrm{~min}$ ), the conversion of $\alpha_{\mathrm{s} 1}-\mathrm{CN}$ (f1-9) at the sites $\mathrm{Lys}_{3}-\mathrm{His}_{4}, \mathrm{Ile}_{6}-\mathrm{Lys}_{7}$, and $\mathrm{His}_{8}-\mathrm{Gln}_{9}$ could explain the accumulation of the $\alpha_{\mathrm{s} 1} \mathrm{CN}$ (f 4-9), (f1-8), and (f16) fragments, whereas $\alpha_{\mathrm{s} 1}-\mathrm{CN}$ (f10-17) and (f10-16) degradation (at the $\mathrm{Gln}_{13}$ - $\mathrm{Glu}_{14}$ bond) produced mainly $\alpha_{\mathrm{s} 1^{-}}$ CN (f10-13).

The accumulation of $\alpha_{\mathrm{s} 1}-\mathrm{CN}$ (f17-21) might originate from cleavage of the $\mathrm{Leu}_{21}-\mathrm{Arg}_{22}$ bond of $\alpha_{\mathrm{s} 1} \mathrm{CN}$ (f1723). The charged $\alpha_{\mathrm{s} 1}-\mathrm{CN}$ (f22-23) and (f1-3) fragments probably eluted early in the chromatogram and were thus not detectable.

Amino acid analysis of the purified GMP showed more than $89 \%$ identity with the calculated composition, except for Thr, Leu, and Gly (70, 62, and 79\%, respectively). Moreover, the contents of Tyr, Phe, His, and Arg were negligible, allowing GMP to be considered pure. 


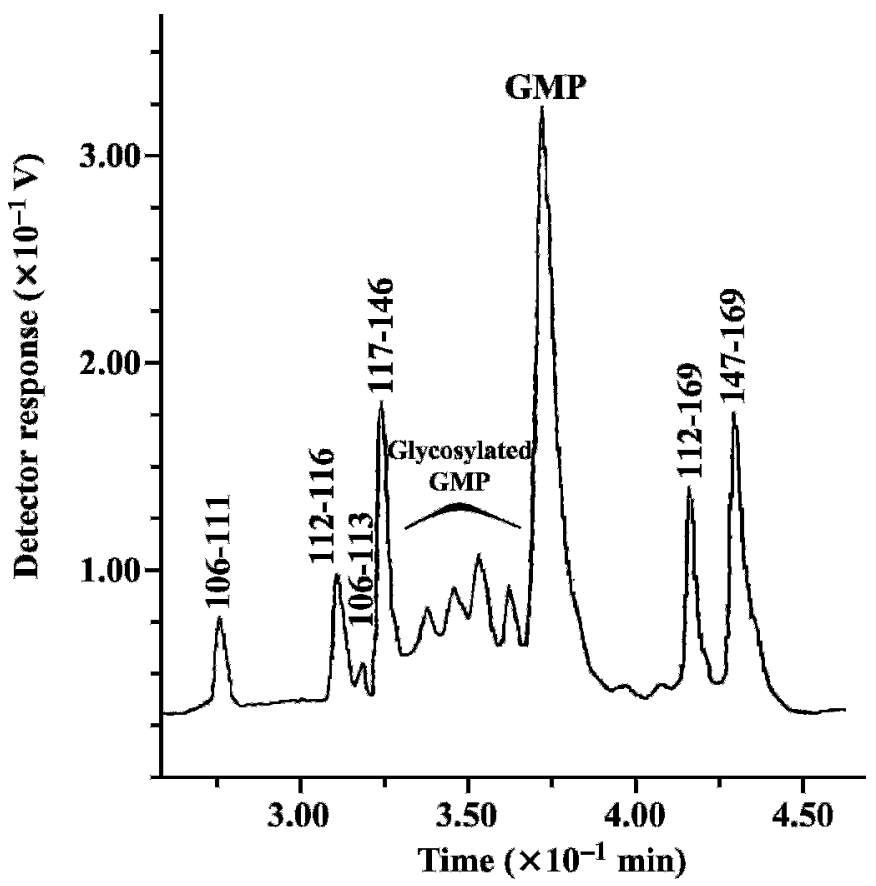

Figure 5. Reversed-phase HPLC patterns of GMP hydrolysis products after $30 \mathrm{~min}$ of incubation at $37^{\circ} \mathrm{C}$ with purified Lactobacillus helveticus Zuc2 cell envelope proteinase. GMP = undigested glycomacropeptide (not glycosylated fraction); glycosylated GMP = undigested glycomacropeptide (glycosylated fractions).

The incubation of GMP with CEP up to 30 min did not produce a spectrum of hydrolyzed peptides as wide as that obtained from $\alpha_{\mathrm{s} 1}$-CN (f1-23) hydrolysis, because approximately $70 \%$ of the substrate (GMP and glycosylated GMP fractions) remained undigested (Figure 5). The main peptide fragments detected in the reaction mixture were $\kappa$-CN (f106-111), (f106-113), (f112-116), and (f117-146) as well as the carboxy-terminus (f112149) and (f147-169) (Figure 5), thus suggesting that Lys $_{111}-\mathrm{Lys}_{112}, \mathrm{Lys}_{116}$-Thr 117 , and Leu ${ }_{146}$-Glu 147 were the sole sensitive bonds. A similar degradation profile was obtained by Sick et al. (1990) during GMP digestion by tripsin.

Cell Fractionation and Partial Characterization of Membrane-Fraction Proteinase. Cell lysis during the protoplastization step, expressed as the percentage of intracellular lactate dehydrogenase released, was less than $5 \%$ of total cells. Cell fractionation demonstrated that proteolytic activity was partitioned between the membrane (46\%) and the cytoplasmatic (17\%) fractions, respectively, whereas the remaining $37 \%$ was associated with the cell wall fraction. This last percentage appeared to be in contrast to that obtained for CEP proteinase activity extracted by $0.5 M \mathrm{P}_{\mathrm{i}}$. A possible explanation could be the environmental differences in residual activity measured on bacterial cells

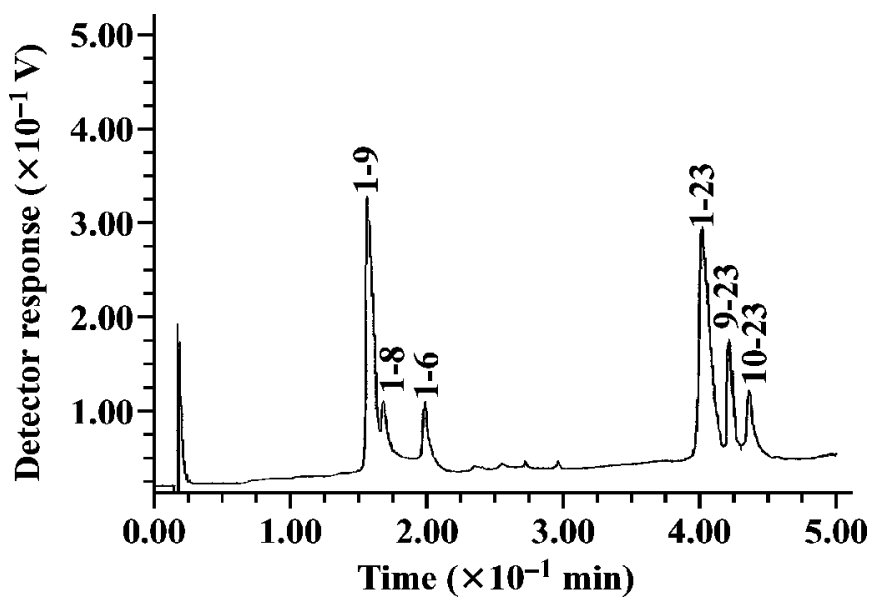

Figure 6. Reversed-phase HPLC profile of $\alpha_{\mathrm{s} 1}-\mathrm{CN}$ (f1-23) hydrolysis products after $30 \mathrm{~min}$ of incubation with Lactobacillus helveticus Zuc2 cells treated by $3 \mathrm{M} \mathrm{LiCl}$.

after $P_{i}$ buffer treatment and those detected on free enzymes in the membrane fractions. Moreover, enzyme autodigestion is highly probable because of the long dialysis process of the cell wall fraction.

More than $80 \%$ of the activity in the membrane fraction was not extractable by $0.5 M \mathrm{P}_{\mathrm{i}}$ but only after membrane solubilization by the treatment with Igepal CA-360, thus suggesting an enzyme anchorage to the membrane. The enzyme contained in the solubilized and dialyzed membrane fraction was eluted from the anion-exchange MonoQ column at $3.0 \mathrm{M} \mathrm{NaCl}$ of the gradient; this could suggest that the MAP is distinct from the CEP observed in the $0.5 M \mathrm{P}_{\mathrm{i}}$ extraction buffer. Approximate $M_{\mathrm{r}}$ of MAP was about $215 \mathrm{kDa}$, as estimated by gel filtration chromatography. The 2 chromatographic steps mentioned permitted only partial purification of MAP from the membrane fraction, so in this preliminary study, detection of the enzyme $M_{\mathrm{r}}$ on SDS-PAGE was not possible.

Casein degradation by the partially purified MAP was much lower than that observed for the purified $\mathrm{CEP}$, showing no evident specificity against the $3 \mathrm{CN}$ fractions. Also, unlike CEP, the degradation of $\alpha_{\mathrm{s} 1}-\mathrm{CN}$ and $\kappa$-CN by MAP did not produce the respective $\alpha_{\mathrm{s} 1}-\mathrm{I}$ and GMP fragments (data not shown).

LiCl-Treated Cells. The RP-HPLC profile of $\alpha_{\mathrm{s} 1^{-}}$ CN (f1-23) after 30 min of incubation with LiCl-treated whole cells is presented in Figure 6. The hydrolytic pattern is completely different from that produced by untreated cells, which substantially reproduces the specificity profile of CEP (data not shown). Only the $\mathrm{His}_{8}-\mathrm{Gln}_{9}$ and $\mathrm{Gln}_{9}-\mathrm{Gly}_{10}$ bonds were cleaved at the assay conditions, resulting in a lower proteolytic activity of treated cells compared with untreated ones. The 
fragment $\alpha_{\mathrm{s} 1}$-CN (f1-8) was further hydrolyzed at the $\mathrm{Ile}_{6}-\mathrm{Lys}_{7}$ bond.

\section{DISCUSSION}

Lactobacillus helveticus Zuc2 seems to carry 2 different proteinases, showing 2 distinct cell envelope anchors. The presence of 2 cell surface proteinases in $L$. helveticus strains was first suggested by Pederson et al. (1999).

\section{CEP}

The inability of Ca-free buffers to remove CEP was also reported by Martin-Hernandez et al. (1994) for the L. helveticus L89 strain. A substantial release of CEP from $L$. helveticus Zuc2 was achieved only by extracting buffer at an ionic strength higher than $250 \mathrm{mM}$; such a value is reported as the limit beyond which electrostatic interactions are maximally weakened (Dill, 1990). The use of a specific inhibitor during the release process allowed us to exclude an autoproteolytic event promoted by conformational changes, possibly consequent to increasing the ionic strength of the extractant. Moreover, the stabilizing effect of the $\mathrm{Ca}^{2+}$ ion reported for the lactococcal CEP anchor (Laan and Konings, 1989) was excluded for the L. helveticus Zuc2 CEP, which is extractable in the presence of high $\mathrm{CaCl}_{2}$ concentrations. The same results were also observed for CEP release from $L$. acidophilus BGRA 43 and $L$. delbrueckii ssp. bulgaricus BGPF $_{1}$ (Fira et al., 2001). These considerations and the low recovery of the proteinase in the cell wall fraction suggest the absence of the LPXTG sorting motif, which leads to the covalent linkage of lactococcal cell-wall proteinase (PrtP) to the peptidoglycan (Navarre and Schneewind, 1999), whose lack was observed by Pederson et al. (1999) and Germond et al.(2003) in proteinase PrtH from L. helveticus CNRZ 32 and PrtB proteinase from $L$. delbrueckii ssp. bulgaricus NCDO 1489, respectively, causing the authors to hypothesize a cell wall attachment of the CEP by electrostatic forces.

The reassociation of proteinase with S-layer monomers during the exhaustive dialysis of the $5 \mathrm{M} \mathrm{LiCl}$ extract supports the hypothesis of an S-layer involvement in the anchorage of the enzyme to the cell surface. S-Layer proteins could be the adhesion site for the CEP, as previously reported for a high $M_{\mathrm{r}}$ amylase in Bacillus stearothermophilus DSM 2358 (Egelseer et al., 1995), subtilase from Bacillus and Clostridium spp. (Schmidt et al., 1995), and pullulanase in Thermoanaerobacterium thermosulfurigenes EM1 (Matuschek et al., 1994). However, this is in contrast with the observation that a small amount (5\%) of CEP is released by thoroughly washing $L$. helveticus Zuc2 cells in $0.5 M \mathrm{P}_{\mathrm{i}}$ buffer also after the complete removal of the S-layer by $3 M \mathrm{LiCl}$. Alternatively, both CEP and S-layer proteins could be linked to the underlying peptidoglycan or to the secondary cell-wall polymers by electrostatic interactions (Sara and Sleytr, 2000) through homologous sequences. In fact, Pederson et al. (1999) demonstrated that the W domain of proteinase PrtH from L. helveticus CNRZ 32 is homologous (up to $33 \%$ ) to the C-terminal domain of the S-layer protein family of Lactobacillus, thus suggesting its possible role in cell-wall binding by a mechanism similar to S-layer protein anchorage (Boot et al., 1995).

The $\mathrm{pH}$ and the temperature optima were in accordance with those reported for L. helveticus CEP (Martin-Hernandez et al., 1994; Ono et al., 1997). The retained activity at $60^{\circ} \mathrm{C}$ assumes a practical usefulness, because the L. helveticus Zuc2 strain belongs to the starter microbiota of Grana cheese, whose technology requires a cooking temperature of approximately $55^{\circ} \mathrm{C}$.

The complete inhibition obtained by PMSF includes CEP in the serine proteinase class. Moreover, reversible inhibition of pepstatin was less than $10 \%$, suggesting that the enzyme does not belong to the aspartyl protease family, although some enzymes of this type are not influenced by this inhibitor-this in spite of its ability to produce GMP and $\alpha_{\mathrm{s} 1}$-I peptides, which are more typically produced by the action of aspartyl proteases on $\mathrm{Phe}_{105}-\mathrm{Met}_{106}$ and $\mathrm{Arg}_{22}-\mathrm{Phe}_{23}$ bonds of $\kappa$ - and $\alpha_{\mathrm{s} 1^{-}}$ $\mathrm{CN}$, respectively. However, a high susceptibility of the former bond to the lactococcal serin-type proteinase was also reported by Kunji et al. (1996). The relative accumulation of such a peptide in the first step of $\kappa$-CN hydrolysis (Figure 3 ) appears to be consistent with the resistance of the isolated GMP to the CEP activity (Figure 5).

Cell envelope proteinase specificity resembles that of proteinase PrtP I, primarily degrading $\beta$ - $\mathrm{CN}$, and to a lesser extent $\kappa$-CN and $\alpha_{\mathrm{s} 1}-\mathrm{CN}$, whereas the MAP specificity cannot be assigned to either the P I or the P III type (Kunji et al. 1996). The behavior of both the proteinases against $\alpha_{\mathrm{s} 1}$-CN was different from that of L. helveticus CRL 1062, which preferentially digests this protein (Hébert et al., 1999).

Cell envelope proteinase cleaves $\alpha_{\mathrm{s} 1}-\mathrm{CN}$ (f1-23) differently from other L. helveticus proteinases (Kunji et al., 1996; Ono et al., 1997; Pederson et al., 1999; Oberg et al., 2002). In fact, L. helveticus Zuc2 CEP hydrolyzes all the cleavage sites of all the proteinases of the same species, and it is also active on the $\mathrm{Lys}_{3}-\mathrm{His}_{4}$ bond in the peptide amino-terminus domain. Such a bond was not even split by the CEP of the strain L. helveticus L 89, isolated from Grana cheese whey (Martin-Hernandez et al., 1994), as was the strain used in this study. 
The amino-terminus region of $\alpha_{\mathrm{s} 1}-\mathrm{CN}$ [ $\alpha_{\mathrm{s} 1}-\mathrm{CN}$ (f1-9)] is hydrolyzed only by intracellular postproline $\mathrm{PepO}_{2}$ and $\mathrm{PepO}_{3}$ endopeptidases from $L$. helveticus CNRZ 32, at the $\mathrm{Pro}_{5}-\mathrm{Ile}_{6}$ bond, under cheese conditions (Sridhar et al., 2005); moreover, those authors demonstrated that the $\mathrm{Lys}_{3}-\mathrm{His}_{4}$ and $\mathrm{Lys}_{7}-\mathrm{His}_{8}$ bonds of the same peptide were sensitive to the action of endopeptidase PepE. This underlines the unique specificity of $L$. helveticus Zuc2 CEP.

The low affinity of CEP toward $\alpha_{\mathrm{s} 1}-\mathrm{CN}$ seems to be in contrast with the high activity observed on the $\alpha_{\mathrm{s} 1^{-}}$ CN (f1-23) substrate, probably resulting from a different accessibility between the free $\mathrm{Arg}_{1}-\mathrm{Phe}_{23}$ sequence and the whole protein. In fact, an altered cleavage in the $\mathrm{Arg}_{1} \mathrm{Phe}_{23}$ sequence of $\alpha_{\mathrm{s} 1}$-CN compared with the free $\alpha_{\mathrm{s} 1}-\mathrm{CN}$ (f1-23) peptide was observed previously (Martin-Hernandez et al., 1994).

\section{MAP}

The resuspension of the cell membrane fraction in $\mathrm{Ca}^{2+}$ free buffer did not produce an appreciable release of MAP, thus demonstrating its resistance to autoproteolysis in situ. The use of a membrane destructuring detergent to release MAP suggests the strong association of the enzyme with the membrane structure, as previously hypothesized for L. helveticus L89 (MartinHernandez et al., 1994) and L. helveticus CRL 1062 (Hébert et al., 1999).

The hydrolyzing activity toward whole CN fractions as well the lack of sensitive bonds in the amino-terminus of the $\alpha_{\mathrm{s} 1}-\mathrm{CN}$ (f1-23) peptide clearly distinguished MAP from the endopeptidases previously identified in L. helveticus (Fenster et al., 1997; Sridhar et al., 2005).

The stronger activity of CEP compared with that of MAP observed in intact cells could be the result of either the observed lower enzyme activity or a more peripheral location of the former, but also a difference in the specific activity.

Work is in progress to confirm the presence of the second proteinase in the L. helveticus Zuc2 strain and to better characterize it in order to establish the role of the 2 different proteinases during the growth of such species in cheese whey. Also, the simple extraction method used in this research will be applied to selectively recover the CEP from different $L$. helveticus strains, with the aim of checking the correlation between the ability of proteinases to produce angiotensinconverting enzyme-inhibiting peptides (or antihypertensive peptides, or both) from $\mathrm{CN}$ and determine their substrate specificity.

\section{CONCLUSIONS}

The results of this study suggest the presence of 2 different proteinases on the cell surface of the $L$. helvet $i$ - cus Zuc2 strain, although further evidence should be acquired to better characterize the MAP. The different mechanisms of enzyme linkage to the cell surface we observed allow for selective extraction of the 2 proteinases.

In particular, because of the ability, demonstrated elsewhere, for $L$. helveticus whole cells to produce bioactive (antihypertensive) peptides after $\mathrm{CN}$ digestion, the possibility of using an easy, discriminative extraction method for the cell envelope-anchored enzyme (CEP) constitutes an important prerequisite for obtaining a deeper knowledge of the role of the enzyme involved in production of the bioactive (antihypertensive) peptides.

\section{ACKNOWLEDGMENT}

Zucchelli cheese factory, which belongs to the Grana Padano consortium, is acknowledged for kindly providing natural whey cultures used in this study.

\section{REFERENCES}

Boot, H. J., C. P. H. M. Kolen, and P. H. Pouwels. 1995. Identification, cloning and nucleotide sequence of a silent S-layer protein gene of Lactobacillus acidophilus ATCC 4356 which has extensive similarity with the S-layer gene of this species. J. Bacteriol. 177:7222-7230.

Christensen, J. E., J. R. Broadbent, and J. L. Steele. 2003. Hydrolysis of casein-derived peptides $\alpha_{\mathrm{s} 1}$-casein (f1-9) and $\beta$-casein (f193209) by Lactobacillus helveticus peptidase deletion mutants indicates the presence of a previous undetected endopeptidase. Appl. Environ. Microbiol. 69:1283-1286.

Dill, K. A. 1990. Dominant forces in protein folding. Biochemistry 29:7133-7155.

Egelseer, E., I. Schocher, M. Sara, and U. B. Sleytr. 1995. The Slayer from Bacillus stearothermophilus DSM 2358 funtions as an adhesion site for high molecular-weight amylase. J. Bacteriol. 177:1444-1451.

Exterkate, F. A., A. C. Alting, and C. J. Slangen. 1991. Specificity of two genetically related cell-envelope proteinases of Lactococcus lactis subsp. cremoris towards $\alpha_{\mathrm{s} 1}$-casein (f1-23)-fragment. Biochem. J. 273:135-139.

Fenster, K. M., K. L. Parkin, and J. L. Steele. 1997. Characterization of thiol-dependent endopeptidase from Lactobacillus helveticus CNRZ 32. J. Bacteriol. 179:2529-2533.

Fira, D., M. Kojic, A. Banina, I. Spasojevic, I. Strahinic, and L. Topisirovic. 2001. Characterization of cell envelope-associated proteinases of thermophilic lactobacilli. J. Appl. Microbiol. 90:123-130.

Germond, J. E., M. Delley, C. Gilbert, and D. Atlan. 2003. Determination of the domain of the Lactobacillus delbrueckii subsp. bulgaricus cell surface proteinase PrtB involved in attachment to the cell wall after heterologus expression of the prtB gene in Lactococcus lactis. Appl. Environ. Microbiol. 69:3377-3384.

Hébert, E. M., R. R. Raya, and G. S. de Giori. 1999. Characterization of cell-envelope proteinase from Lactobacillus helveticus. Biotechnol. Lett. 21:831-834.

Kaminogawa, S., T. R. Yan, N. Azuma, and K. Yamauchi. 1986. Identification of low molecular weight peptides in Gouda-type cheese and evidence for the formation of these peptides from 23 $\mathrm{N}$-terminal residues of $\alpha_{\mathrm{s} 1}$-casein by proteinases of Streptococcus cremoris H61. J. Food Sci. 51:1253-1256.

Kunji, E. R. S., I. Mierau, A. Hagting, B. Poolman, and W. N. Konings. 1996. The proteolytic system of lactic acid bacteria. Antoine van Leeuwenhoek 70:187-221. 
Laan, H., and W. N. Konings. 1989. Mechanism of proteinase release from Lactococcus lactis subsp. cremoris Wg2. Appl. Environ. Microbiol. 55:3101-3106.

Maeno, M., N. Yamamoto, and T. Takano. 1996. Identification of an antihypertensive peptide from casein hydrolisate produced by a proteinase from Lactobacillus helveticus CP 790. J. Dairy Sci. 79:1316-1321.

Makdor, S. A., P. S. Tong, and M. El Soda. 2000. Ripening of Cheddar cheese with added attenuated adjunct cultures of lactobacilli. J. Dairy Sci. 83:1684-1691.

Martin-Hernandez, C., A. Alting, and F. Extertake. 1994. Purification and characterization of the mature, membrane associated cellenvelope proteinase of Lactobacillus helveticus L89. Appl. Microbiol. Biotechnol. 40:828-834.

Matar, C., J. C. Valdez, M. Medina, M. Rachid, and G. Perdigon. 2001. Immunomodulating effects of milks fermented by Lactobacillus helveticus and its non-proteolytic variant. J. Dairy Res. 68:601-609.

Matuschek, M., G. Burchhardt, K. Sahm, and H. Bahl. 1994. Pullulanase of Thermoanaerobacterium thermohydrosulfurigenes EM1 (Clostridium thermosulfurogenes): Molecular analysis of the gene, composite structure of the enzyme, and a common model for its attachment to the cell surface. J. Bacteriol. 176:3295-3302.

Morishita, T., Y. Deguchi, M. Yajima, T. Sakurai, and T. Yura. 1981. Multiple nutritional requirements of lactobacilli: Genetic lesions affecting amino acid biosynthetic pathways. J. Bacteriol. 148:67-71.

Mozes, N., and S. Lortal. 1995. X-ray photoelectron spectroscopy and biochemical analysis of the surface of Lactobacillus helveticus ATCC 12046. Microbiology 141:11-19.

Navarre, W. W., and O. Schneewind. 1999. Surface proteins of grampositive bacteria and mechanisms of their targeting to the cell wall envelope. Microbiol. Mol. Biol. Rev. 63:174-229.

Oberg, C. J., J. R. Broadbent, M. Strickland, and D. J. Mc Mahon. 2002. Diversity in specificity of the extracellular proteinases in Lactobacillus helveticus and Lactobacillus delbrueckii subsp. bulgaricus. Lett. Appl. Microbiol. 34:455-460.

Ono, H., N. Yamamoto, M. Maeno, T. Takano, and H. Momose. 1997. Purification and characterization of a cell-wall associated proteinase of Lactobacillus helveticus CP53. Milchwissenschaft $52: 373-377$.
Pederson, J. A., G. J. Mileski, B. C. Weimer, and J. L. Steele. 1999. Genetic characterization of a cell envelope-associated proteinase from Lactobacillus helveticus CNRZ32. J. Bacteriol. 181:45924597.

Sara, M., and U. B. Sleytr. 2000. Minireview-S-layer proteins. J. Bacteriol. 182:859-868.

Scolari, G., V. Bottazzi, and B. Battistotti. 2002. Antihypertensive effect of peptides produced by Lactobacillus helveticus in fermented milk. Pages 47-53 in Proc. Cheese: Technology, Ripening and Characterization. October 29, 2002, Parma, Italy. Associazione Italiana Tecnici del Latte, Reggio Emilia, Italy.

Scolari, G., and M. Vescovo. 1996. Peptidase localization in Lactobacillus casei $5 \mathrm{Mn} 373$ by stable protoplast formation. Biotechnol. Techn. 10:687-692.

Scolari, G., and M. Vescovo. 2004. Use of X-prolyl-dipeptidyl aminopeptidase electrophoretic mobility as a tool to differentiate Lactobacillus species of dairy relevance. Ann. Microbiol. 54:529-542.

Scolari, G., M. Vescovo, and G. Rossi. 1996. Substrate models for $L$. casei peptidases profiling. Int. Dairy J. 6:921-925.

Seppo, L., T. Jauhiainen, T. Poussa, and R. Korpela. 2003. A fermented milk high in bioactive peptides has a blood pressurelowering effect in hypertensive subjects. Am. J. Clin. Nutr. 77:326-330.

Schmidt, B. F., L. Woodhouse, R. M. Adams, T. Ward, S. E. Mainzer, and P. J. Lad. 1995. Alkalophilic Bacillus sp. strain LG12 has a series of serine proteinase genes. Appl. Environ. Microbiol. 61:4490-4493

Sick, H., K. Kaiser, and A. Henne. 1990. The action of glycomacropeptide (GMP) on trypsin activity in vitro. Milchwissenschaft 45:76-78.

Smeds, A., P. Varmanen, and A. Palva. 1998. Molecular characterization of a stress inducible gene from Lactobacillus helveticus. J. Bacteriol. 180:6148-6153.

Sridhar, V. R., J. E. Hughes, D. L. Welker, J. R. Broadbent, and J. L. Steele. 2005. Identification of endopeptidase genes from the genomic sequence of Lactobacillus helveticus CNRZ32 and the role of these genes in hydrolysis of model bitter peptides. Appl. Environ. Microbiol. 71:3025-3032.

Yamamoto, N., H. Ono, M. Maeno, Y. Ueda, T. Takano, and H. Momose. 1998. Classification of Lactobacillus helveticus strains by immunological differences in extracellular proteinases. Biosci. Biotechnol. Biochem. 62:1228-1230. 